\title{
HIGHER TECHNOLOGICAL EDUCATION
}

\author{
By Prof. J. F. BAKER, O.B.E. \\ Department of Engineering, University of Cambridge
}

$\mathrm{O}^{\mathrm{N}}$ $\mathrm{NE}$ of the liveliest discussions at the Congress of the Universities of the Commonwealth, held in Cambridge during July 13-17, arose at the meeting on "Higher Technological Education". The opening speakers were Prof. J. F. Baker, head of the Department of Engineering, Cambridge, Dr. K. Venkataraman, director, Department of Chemical Technology, University of Bombay, Prof. J. D. Baxter, director, New South Wales University of Technology, and Sir Roderick Hill, rector of the Imperial College of Science and Technology.

Prof. Baker gave a brief outline of the position of technology in the universities of the United Kingdom. He sketched the completely integrated activities of a typical department, the main interest and responsibility of which is the education of the undergraduate. The three-year undergraduate course concentrates on a grounding in fundamental science and in mathematics with the added discipline of dealing with particular problems in detail. Engineers have a philosophy of their own, and so the teaching must be in the hands of engineers. To remain engineers, teaching officers must engage in applied research, or consulting work of the right standing, which keeps them in intimate contact with industry. When their research has established their school as the leading authority in a particular field, it must be opened to postgraduate students returning after four or five years industrial experience for an intensive course of instruction. These mature men, who return with practical experience and a knowledge of industrial processes and techniques, are ripe for specialist instruction in the highly skilled operation of applying scientific method to the solution of industrial problems which they could not have appreciated in their undergraduate days. The domestic difficulties facing industry in freeing and paying for these men are great but not insurmountable. If they are not overcome the great pressure of engineering development will lead to a demand for lengthened courses for all undergraduates in which, at great expense, immature minds will be forced into moulds turning out, in. the end, technicians and not technologists.

Dr. Venkataraman described the position in India. There the All-India Council for Technical Education, constituted in 1946, recognized the advantages of upgrading and enlarging existing institutions, and as a result large capital and recurring grants were made to fourteen departments or colleges of technology. In spite of this, technological institutions are faced with many problems, particularly the shortage of highly qualified and experienced teachers. The surprising statement was made that India turns out more chemical engineers than does Great Britainand the output is in excess of the demand. The Ministry of Education has instituted a number of paid apprenticeships; but many more are required and industry must be persuaded to undertake this responsibility and also to support research in the universities, as Imperial Chemical Industries and other firms do in Great Britain. Dr. Venkataraman also made a plea for the encouragement of consulting work in the universities so that the staff can keep in touch with practice.

Prof. Baxter gave a most interesting account of the development and present state of the New South Wales University of Technology, the first of its kind in the British Commonwealth. Founded in 1949, it bas already made rapid progress, having been fortunate in collecting a high-grade staff. There is, in the highly industrialized State of New South Wales, with its 65,000 technical students, an open road from the technical colleges to the University. The University of Technology decided, in 1951, to accept responsibility for part-time diploma courses. Two principles are followed: first, that a substantial amount of practical training is included in all courses ; and second, that study of the humanities is not neglected. A typical arrangement is to devote to academic studies two twelve-week terms, with a twoweek vacation between, leaving half the year free for supervised practical experience. In all courses time is devoted to such subjects as English, history and philosophy during the first two years of a course, while in the third and fourth years the student selects one of these subjects for further study. To the present courses in physics, chemistry and the three main branches of engineering are to be added in the future further specialized engineering courses and such subjects as textiles, rubber, plastics, food technology, industrial ceramics and building science.

Sir Roderick Hill turned to a more philosophical aspect of the problems posed by the advance of technology. He considered how we can escape the unregulated impact of applied science and asked what price the universities must pay for a partner ship between it and the familiar academic disciplines. He feels it difficult to reconcile a vocational training with the broader education necessary to equip a man for life, but sees no reason why technological studies should not provide that rigorous intellectual discipline needed to train human excellence. Sir Roderick concluded with a plea that motives other than the need to survive must be put before young people; higher aspirations must be invoked.

'The chairman, Dr. H. R. Raikes, vice-chancellor of the University of the Witwatersrand, before inviting general discussion, emphasized the importance of the following points: that technology should remain in the universities; that the courses should deal with fundamentals and be not too long; and that provision should be made for selected students to return eventually for postgraduate instruction.

Dr. A. E. Cameron, president, Nova Scotia Technical College, gave a picture of the position in Canada where eleven institutions cover almost all branches of engineering but naval architecture. The courses are of four years duration, the first two being devoted to science and the humanities and the last two to technology. However, such is the pressure of the science studies that the humanities and social science are assuming a minor role.

Dr. P. Dunsheath, London, stressed the vital necessity of close relations between industry and the 
universities, since industry is the controlling factor of modern life. Industry must learn what the universities do and how graduates can be introduced, particularly into small firms. The universities must learn to appreaiate the nature and purpose of industry. $\mathrm{He}$ pointed out that the cessation of ear-marked grants throws an increased responsibility on the universities, since they must not neglect the needs of industry.

Prof. W. G. Sutton, Witwatersrand, claimed that in the technological field his university has the same aims as Cambridge. He feels that too much respect for research must not be encouraged among students of technology, but that postgraduate courses of instruction are desirable. $\mathrm{He}$ ended with a warning to New South Wales that South Africa from bitter experience knows the deficiencies of technological institutions as centres of higher education.

Prof. J. R. Daymond, Natal, in his turn claimed allegiance to the Cambridge aims. The University of Natal encourages students to graduate in science and then to read engineering for two further years. Prof. Daymund, taking more than twice the allowance of time given to other speakers, pleaded eloquently for a broader base to be given to the educational pyramid and for universities to resist the tendency to train in specific skills.

Prof. W. H. Hutt, Cape Town, who stressed the fact that he is not an engineer, expressed entire agreement with the views Prof. Baker expressed in opening the session, and summed up the discussion in the apt phrase, "Let the university teach 'why' and leave life to teach "how","

\section{ACADEMIC MOBILITY IN THE BRITISH COMMONWEALTH}

\author{
BY SIR CHARLES MORRIS \\ Vice-Chancellor, University of Leeds
}

$\mathrm{A}^{\mathrm{T}}$

$T$ the recent Congress of Universities of the Commonwealth at Cambridge, at which more than eighty universities and university colleges were represented, there was a lively and most interesting discussion on "Academic Mobility in the Commonwealth". A previous Congress five years ago at Oxford had pressed for vigorous action to be taken to promote interchange of both senior and junior scholars between British countries; and following that Congress the United Kingdom Government made available through the British Council rather more than $£ 30,000$, so that a start could be made with the pilot scheme. Under this scheme, provision was made for three categories of scholars: very senior and distinguished people paying short visits on the invitation usually of several universities; professors and other established scholars on leave from their own universities for about a year ; and junior scholars able to spend one or two years abroad at the beginning of their professional academic careers. It was clear from the discussion at the Congress that the minds of the universities in other Commonwealth countries have been working along the same lines, and a great deal of progress has been made in many countries.

The British Council scheme clearly covers only a part of the total movement between universities, but its role was recognized to be an extremely valuable one; the Congress showed itself particularly interested in the visits arranged in the first category mentioned above, namely, the short visits of very senior and distinguished people. In the meantime, it was obvious that there are some most desirable developments not covered or certainly not sufficiently covered by any of the arrangements in operation within the Commonwealth-in particular, movement between the universities and university colleges in the Colonial countries and the rest of the Commonwealth, and cross-movement between the 'peripheral' countries of the Commonwealth themselves. On the first point it was announced to the Congress that the United Kingdom Government has now made a fund available to enable similar arrangements to be made with the university institutions of the Colonial countries.

After a lively debate the Congress passed a resolution urging member universities to seek suitable opportunities for approaching their Governments with the request that they should contribute to "a co-operatively administered Commonwealth Interchange Fund". It need not be said that the Congress showed itself well aware of the high desirability of movement between the universities of British countries and of non-British countries, notably the countries of Western Europe and the United States. Tribute was paid especially to the success of the Fulbright scheme.

This was perhaps the most interesting instance of a resolution of the last Congress five years ago being actually brought into force. It was a significant instance. The zeal for promoting movement between universities has greatly increased in the past five years. Many speakers at the Cambridge meeting testified to the great value of interchange of undergraduates and young graduates; and a great deal of thought was given to the well-known problems involved in making it easier for members of the academic staff of a university in one country to move to a permanent appointment in another country. There was no kind of suggestion by anybody that too much importance was being attached to such movement or that the zeal for these developments was getting out of proportion. The only hesitant voices were from those who feared that movement between British and non-British universities might possibly suffer. There is no question that the Congress as a whole was most desirous that this should not be so.

\section{THE UNIVERSITY OF LIVERPOOL (1903-53) \\ BY SIR HENRY COHEN \\ Professor of Medicine, University of Liverpool}

T' $\mathrm{T}$ is a happy circumstance that this year's meeting I in Liverpool of the British Association for the Advancement of Science should coincide with the jubilee of the granting of the Charter to the University of Liverpool. For the story of the University's first fifty years is an enviable record both of notable men of science and of man's successful quest for knowledge. A University College had existed for twentyone years before full university status was attained, and had been served by many impressive scientific figures, including Oliver Lodge who, after occupying the Lyon Jones chair of physics for nineteen year's, had resigned to become the first principal of the University of Birmingham. 